\title{
Design Research in Fraction for Prospective Teachers
}

\author{
Ekasatya Aldila Afriansyah \\ STKIP Garut \\ Garut, Indonesia \\ e_satya@yahoo.com
}

\author{
Jarnawi Afgani Dahlan \\ Universitas Pendidikan Indonesia, \\ Bandung, Indonesia
}

\begin{abstract}
Many recent studies found that students tended to have difficulty in grasping the concept of fraction. In order to overcome all the difficulties, this study presents a sequence of classroom activities aimed at constructing the understanding of fraction. This study enables prospective teachers as students to work with contextual situations. Realistic Mathematics Education (RME) underlies the design of the context and the activities. The aim of the research contributes to practical domains especially in mathematics learning using Realistic Mathematics Education. Design research was chosen as an appropriate means to achieve the aim. It was conducted in three phases, preliminary design, teaching experiment (first and second cycles), and retrospective analysis. This study involved two classes of prospective teachers (first cycle); some prospective teachers were analyzed in detail which was held at STKIP Garut. The result of this study showed that a sequence of activities could bring prospective teachers' learning from the contextual situation to more formal situation and give them the way of idea in teaching it. They could do every contextual problem with their reasoning. This result was supported by a sequence of classroom activities that have been given. It could be seen from comparing pre-test and post-test, prospective teachers' work increased and many strategies with reasoning were come up in the end of learning. Learning trajectory on this study could be used for school learning.
\end{abstract}

Keywords-Concept of Fraction; Prospective Teachers, Contextual Situations, Realistic Mathematics Education, Design Research

\section{INTRODUCTION}

Educational success is influenced by the effectiveness of educators to manage learning environments. A good learning environment is expected to create a good quality of education. G. Thompson [16] states that "Education is the environmental influences on individuals to make permanent changes in habits, thoughts, attitudes and behavior". In line with these opinions [7] suggested "The primary function of education is guidance to individuals in an effort to meet the needs and desires in accordance with its potential, so that the individual obtains satisfaction in all aspects of personal life and social life".

In Indonesian curriculum of education, a lot of subjects have to be studied by students at schools, especially mathematics. Improving the quality of learning of mathematics not merely because of the mathematics urgency, but also to improve the ability of Indonesian students. Based on the mathematics test results, Trends in International Mathematics and Science Study (TIMSS) and the Program for International Student Assessment (PISA), Indonesian students with a specific range of age represented and obtained poor results as well.

One of the innovations learning approaches that can overcome the problems seen in this study is the application of the approach of Realistic Mathematics Education (RME). RME provides opportunities for students to be more active in learning, because learning is done more centered on the students. RME who sees mathematics as a human activity that has five characteristics, namely: "(1) the use of contexts; (2) the use of models; (3) the use of students' own productions and contructions; (4) the interactive character of teaching process; (5) the intertwinement of various learning strands" [12].

There are many studies in Indonesia, which examines the approach Realistic Mathematics Education in the country, namely [17], [8], and [4]. Meanwhile, studies related to the RME outside Indonesia, including [9], [10], [11]; [1] and [2], [18], [12], [13]; [3], [19], [5], and [15]. Both research in Indonesia and abroad still yet to formulate a topic LIT fractions through RME approach.

After comparing with the research studies that have been done, both in Indonesia and abroad, it was clear that this research has significant difference and has novelty because this study was more comprehensive overall, it revealed LIT of various series of RME learning on each subtopic of fractions.

The target findings from this study is in the form of instructional design through RME approach, especially on the topic of fractions. The shape of the RME instructional design in the form of Hypothetical Learning Trajectory (HLT) has been compiled on each subtopic of fractions. All this HLT is arranged sequentially and systematically to produce more complete learning design of RME which is called the Local Instruction Theory (LIT) on the topic of fractions.

The urgency of this study consisted of: 1) the study of RME approach applied in learning; 2) the study of some HLT which was made based on various subtopics RME approach in fractions; 3) the study of the LIT on the topic systematically collected from the fragments of some HLT based RME approach; and 4) Mathematics school or college level that requires referral of this research to the development of mathematics. 
This research is expected to contribute to the knowledge in providing input on the learning method matter in the form of the trajectory of activities on the topic of mathematics learning fractions. RME approach became basic guidelines for the trajectory of activities of this mathematical learning. In addition, there are some expected contributions to various parties including: 1) for the government, this study can be a reference for policy making; 2) for higher education, the results of this research can be used as a reference in order to increase the cooperation of faculty and students; 3 ) for the lecturer, it can be a reference in planning and implementing learning class; 4) for academicians, it can increase the ability of researching and can be used as a reference for other researchers; and 5) for the public, they gain new knowledge about mathematics education and how to implement RME approach.

\section{METHOD}

The research method of this study that will be discussed are: (a) research approach, (b) data collection including preparation phase, pre-teaching experiment, teaching experiment, post-test, validity and reliability; and (c) data analysis including pre-test, pre-teaching experiment, teaching experiment, and posttest.

The main object of this research is to investigate students' learning of understanding the concept of fraction. For this purpose, design research was chosen as an approach for achieving the research goals and answering the research questions. Reference [3] stated that design research is a type of research methods aimed to develop theories about both the process of learning and the means that are designed to support that learning. Therefore, in this research, a sequence of activities was designed as means to improve educational practices in understanding of fraction concept for prospective teachers.

According to [3], there are three phases of conducting a design experiment, as follows:

\section{- Preliminary Design}

In the preliminary design, the ideas which were implemented here, were inspired by studying the literature. A sequence of instructional activities containing conjectures of students' strategies and thinking was developed. The conjectured hypothetical learning trajectory was developed based on literature, adjusting the students' actual learning during the pilot and teaching experiment.

\section{- Teaching Experiment}

In the teaching experiment, instructional activities were tried, revised, and designed on a daily basis during the teaching experiment as in [12]. The teaching experiment is aimed at collecting data for answering the research questions. In this research, it was conducted through 150 minutes time allocation per meeting. Previously, the lecturer and the researcher discussed the upcoming activity. After each lesson ended, lecturer and researcher made a reflection in order to improve the designed activities.

\section{- Retrospective Analysis}

In the retrospective analysis, all the data collected during the teaching experiment were analyzed. The hypothetical learning trajectory was used as a guideline in answering the research questions; it was compared with students' actual learning.

\section{A. Data Collection}

1) Preparation Phase: In the preparation phase, the data collection was aimed to investigate pre-knowledge of students. It was collected by doing observation class, interview, and pre-test for all students. The information about students' preknowledge was used to fit the initial Hypothetical Learning Trajectory (HLT) considering the aspect of starting point of students. It could be adjusted before the first cycle was started. The classroom situation is also important to be concerned about how the learning process works in the class. It concerns about social norms and socio-mathematical norms. The data were collected during the lesson of the observation class; they were obtained from audio or video recording, and the researcher field notes. The researcher wrote the field notes based on the lists of the observation points.

2) Preliminary Teaching Experiment (first cycle): In the preliminary teaching experiment, the instructional activities were given to four students with respect to the differences in level of understanding (One student with high level, two students with middle level, and one student with low level) which were not different too far. The decision of choosing four students was expected to represent the ability of the other students. Four students who were selected were not from the observation class for the next following phase. In this phase, they would be taught by the researcher or one of mathematics teacher who would do teaching experiment later on; expecting that the lecturer would know better the learning trajectory before the second cycle of teaching experiment is began. During the learning process, it was recorded by one camera focusing to all students. The field notes was also taken by the researcher. The aim of the preliminary teaching experiment is collecting the data to support the adjustment of the initial HLT.

3) Teaching Experiment (second cycle): In the teaching experiment phase, the HLT which has been improved was tried out. It was given to all students in one class, but for the analysis of the experiment was focused on four students only (one group of four students). The data was gathered through two video recording, one camera, and field notes. One video recording was placed in the corner of the classroom in order to record most of the situation of learning process. And another video was placed in front of the group consisting of four students. Also, one camera was used to take some pictures of interesting moments related to the experiment, such as students' strategy when solving the problem. The researcher's role was as an observer and makes some notes; researcher focused to the group of four only. Moreover, the teaching experiment of the second cycle aimed to answer the research question. 
4) Post-Test: In the post-test phase, the test was used to assess students' understanding after the lesson was done. This post-test can measure students' ability whether the lesson is succeeded or not. The test was in the written form consisting of 10 problems. The problems were in the same form with the pre-test. The post-test was given both in the first cycle and the second cycle at the end of the activities. Four students who were the focus of this study were interviewed to get deeper answer on the post-test problem. It was used to find out what their thinking and reasoning toward the problem. In this phase, the data were collected through one video recording (during the post-test and interview session) and field notes of researcher.

5) Validity and Reliability: In this study, the different types of data were involved, such as video observations, students' worksheet, field notes, and interview data. The method of triangulation data was done by involving different types of data. The triangulation data and also testing conjectures of the HLT during the teaching experiment contributed to the internal validity of the data. Data registration was more convincing that researcher works in a reliable way because the data was collected by different methods; collecting data by a video recording is more objective than making field notes.

\section{B. Data Analysis}

1) Pre-Test: In the pre-test phase, the result of pre-test data (the students' answers and calculation) was analyzed to investigate starting points of students in learning about fractions. The test result was expected to reveal students' prior knowledge about fractions; it could direct the HLT in such a way in order to make it appropriates for students.

2) Preliminary Teaching Experiment (first cycle): In the preliminary teaching experiment phase, the video recording and the students' worksheet were analyzed to find out the useful of the learning process. Officially there was a possibility that the conjectures of our HLT was not appropriate with the real situation. The HLT needed improvement because sometimes it fitted students in learning process and sometimes it did not appropriate for them.

3) Teaching Experiment (second cycle): In the teaching experiment phase, the video and the students' worksheet were analyzed; these four students were the focus. Their thinking and also their development from the beginning of the study until the end was analyzed. However, it was still possible to the other students to be analyzed as well. If there was a situation or a statement which was supported the learning process, it was possible that the other student would be included to be analyzed in this study.

4) Post-Test: In the post-test phase, the result of the test was analyzed to measure students' understanding after the lesson has finished. It could also be compared to the result of the pre-test finding out whether there was any improvement or not. The post-test aimed to investigate students' development in understanding the concept of fractions.

5) Reliability: In this study, the reliability of the data analysis covers two aspects, track-ability and intersubjectivity. Giving a clear description on how the work on this study so that the readers easily understand the way of track-ability. The description contains the explanation of the process of how the preparation phase is done, how the teaching experiment phase (first and second cycle) happened, how the research analyzes the data; and also the conclusion. In addition, discussing with colleagues can avoid the researcher's own viewpoint toward data analysis; it is needed to attain inter-subjectivity.

\section{Subject Research}

This study was conducted on the first semester of the academic year 2016/2017. The subjects were the first-level of prospective teachers who signed the course of 'Kapita Selekta Matematika Pendidikan Dasar 1' in STKIP Garut. They were the students and the research subjects as well.

\section{RESULTS AND ANALYSIS}

\section{A. Preliminary Research}

The preliminary study was conducted by the researcher on prospective teachers in Mathematics Education STKIP Garut. The students are o the third semester and have taken the course of 'Kapita Selekta Matematika Pendidikan Dasar 1' in the first semester. They were used as the sample in this preliminary study. The aspects that were measured students' understanding of fractions in detail for each of its subtopics.

Based on the results of the preliminary study, the researcher analyzed the results of students' work on a few questions to reveal the difficulties they experienced. Tracing from the students work based on their understanding of fractions, some fundamental errors that should not be done by the prospective teachers were encountered. Students tend to answer the mathematics problems at a low level and some math problems could not be answered correctly. The students work showed that most students were still unable to think contextually on the formula or procedures. Therefore, when they were given formulas or procedures, the results did not cover the completion of the mathematics problems.

\section{B. Initial Research}

The core of a design research constitutes a cyclic process of designing instructional sequences, testing and revising them in classroom settings, and then analyzing the learning of the class so that the cycle of design, revision, and implementation could begin again as in [14]. This cyclic design could be started again for a couple of times to improve its implementation in a classroom setting. This is why researchers have done two cycles already, in academic year 2015/2016 and 2016/2017. It will also continue to the next academic year, $2017 / 2018$. 
In our study, this type of cyclic design has been implemented on fractions. Based on the result of the try out activity in the first phase of the design research, we did some revisions to change the order of the sequence activities and to add some activities. The result of revision was HLT II in learning fractions. The cycle of the design did not stop at HLT II because we continued the study to the second research. This second research was the initial research of this article. It will also become a grounded research for the next research cycle.

In this design research, there were three situations based on subtopic, i.e. fractions, decimals, and percentage. In addition, this study used some models that were related to the given subtopics, namely number line and percentage bar model. Accordingly, the given subtopics and model have raised contextual situations that obviously have important roles in the learning process.

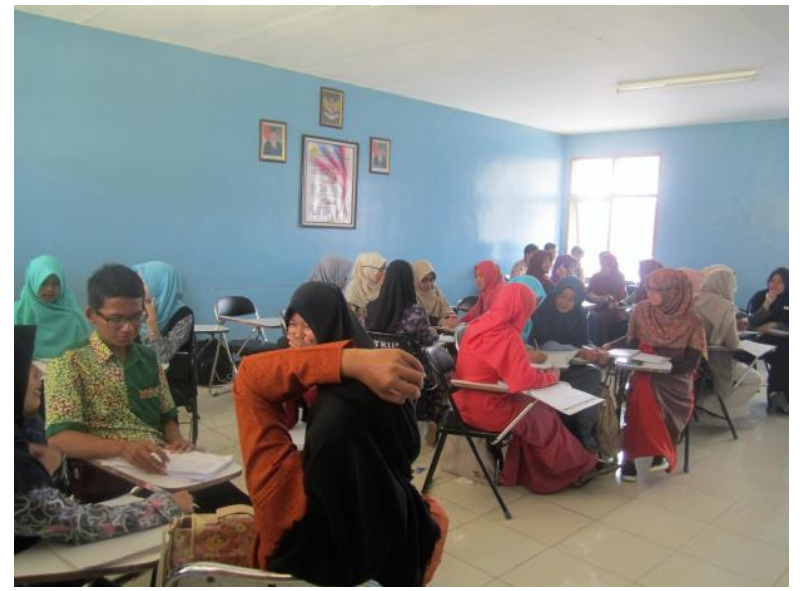

Fig. 1. Students worked in groups

In the practice, the students were divided into a group of four (Fig. 1). They were given a worksheet in each group (Fig. 2 ). In the worksheet, there were some big problems needed to be solved and discussed in group. There were still some students in a class who found it difficult to give reason on their answers. They also felt afraid of making mistakes in answering the given questions and ashamed of committing the mistakes. However, it would not happen because the researchers let the students work in a small group of four. It allowed them to do a discussion in solving the problems and helped the understanding of the topic from their friends' explanation. The reform of learning and teaching mathematics based on RME apparently offers opportunities for students to discuss and construct recognizable contexts.

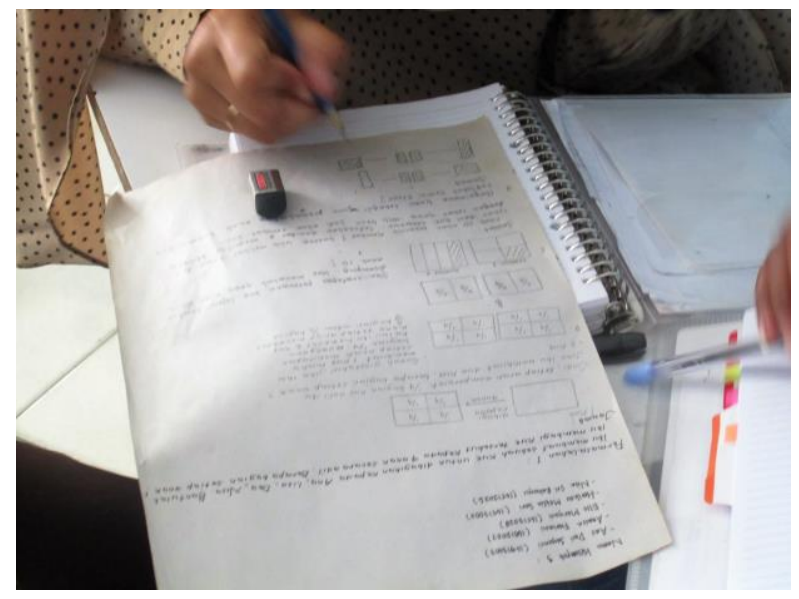

Fig. 2. Students' worksheet

The activities in our Hypothetical Learning Trajectory constituted a sequence of activities from the equivalence of fractions as the basic idea and then continued to explore decimals and percentages. Operations on fractions should be delayed until the concept of fractions and the ideas of the order and equivalence of fractions firmly established [6]. There were six main meetings in the research experiment, including the pretest and post-test. The activities involved contextual problems for all subtopics and one educational game for decimal topic. Some of the activities were found to work out well as expected. The educational game of the decimal operation activity combined with the number line activity worked well (Fig. 3).

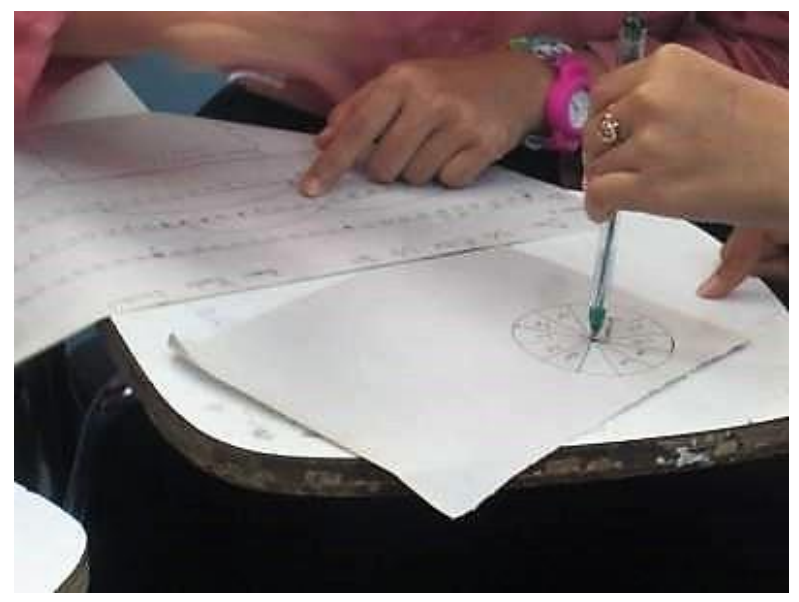

Fig. 3. One Educational game of decimals, 'Decimals Wheel'

The activities were inspired from the grounded research of International Master Program on Mathematics Education (IMPoME) students. The results of some IMPoME's research were taken to be used in learning; it succeeded to enhance students' ability of reasoning. This fact supports the researchers to use some of the result IMPoME's research.

Practically, students could experience with the contextual problems in each subtopics. On the first subtopic that was fractions, the researchers spent more than one meeting. The students were given some contextual problems of fractions. One of contextual problem was about the differences for two 
pieces of cake, the first cake was sliced three times to the same size vertically and the second cake was sliced two times vertically and horizontally of the same size.

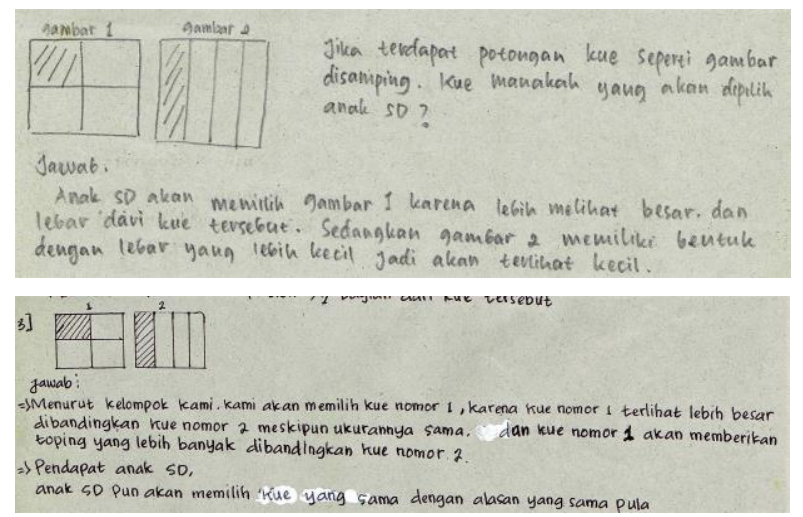

Fig. 4. Two examples of students' answer for fraction problem

There were different answers for the problem "What do you think of elementary students' choice for these two cakes? Which one will they choose?". From this problem, we took two students' answers which gave the same answer (Fig. 4). They answered that elementary students would choose cake number 1 , because it seems bigger than cake number 2 . From this point of view, we can see there is still problem for elementary students. They may choose one form when they have to compare two different forms although having the same size. They did not think of fractions, instead the form only.
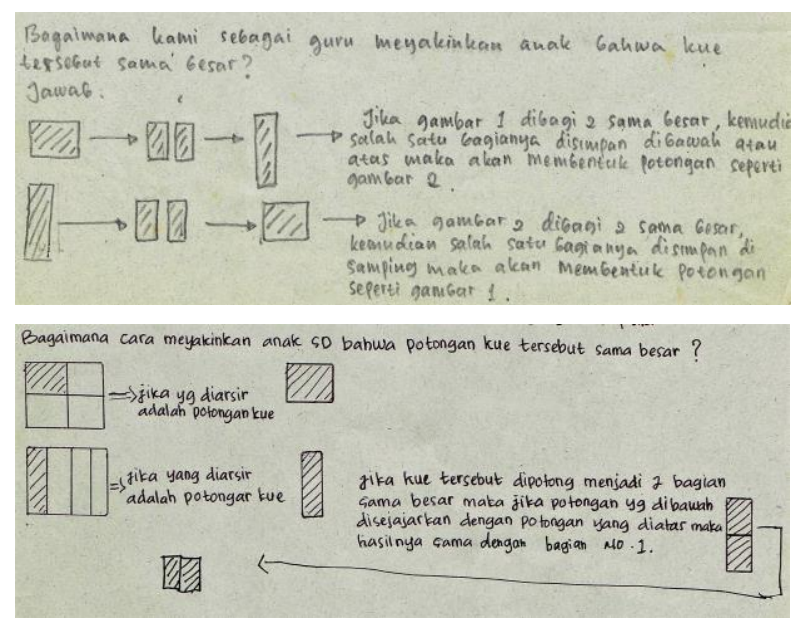

Fig. 5. The other two examples of students' answers for fractions problem

The next problem of fraction was still associated with the previous problem. However, prospective teachers were asked to find out the way they would explain so that the elementary students understand that the two different pieces of cake are the same (Fig. 5). From the two examples of students' answers, we can see these two small groups understand already. They have an easy way as real teachers to explain this problem to their future students. We provided one picture of one prospective teacher representative from her group. She tried to show an easy way explaining the problem as a teacher in front of elementary students (Fig. 6).

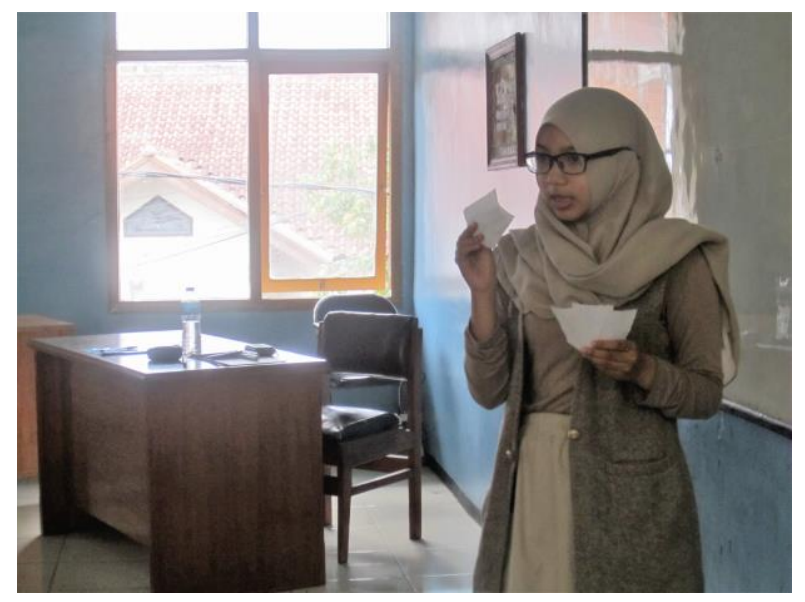

Fig. 6. One of the prospective teacher practiced her ability in explaining problem

One the second subtopic that was decimals, the researchers spent more than two meetings also. We not only provided contextual problem of decimals but also educational games of decimals. We expected our model for decimals, number line, could add students' understanding of decimals. The first problem that we gave to students as prospective teachers was the way they bring to elementary students about the existence of decimals. So we took the best answer for this problem (Fig. 7).

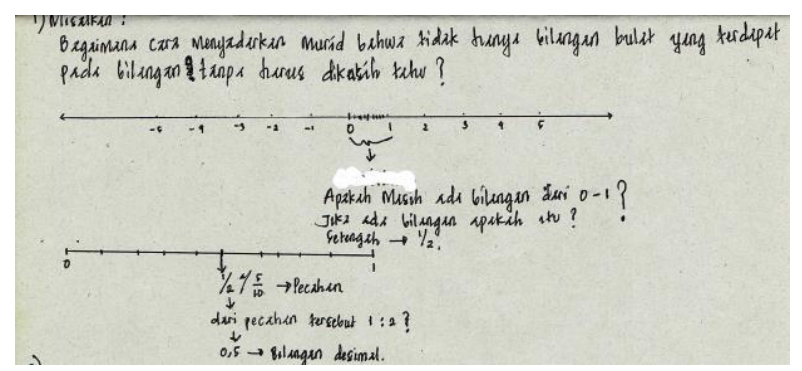

Fig. 7. One student group answer for the first problem of decimals

From the figure, it is seen that this student had a good way of thinking because she started from integer number system. She interpreted the number line and showed a problem. A problem is "What numbers that existed between integers that coincide with each other?". So the answer is not integers number, absolutely, but the other numbers, it can be fractions or decimals forms.

After giving some decimals problem to enhance students understanding of the decimals concept, we continued to an educational game of decimals. The name of the game is 'Decimals Wheel'. On the practice, each group found one representative from their group (Fig. 8). It could continue to find a champion in their class. We could see model for, number line, helped students to add decimals step by step. The number line was not only gave the picture of decimals addition but also constructed students thinking about decimals operation concept. 


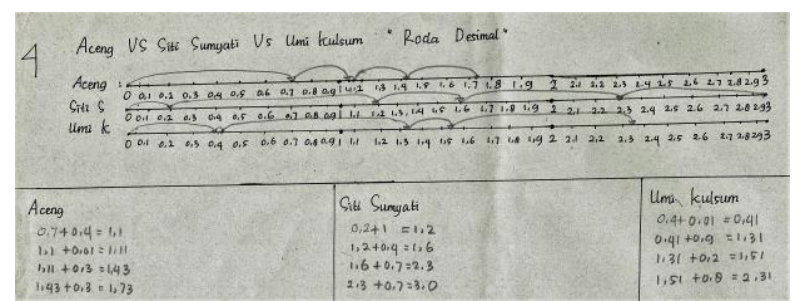

Fig. 8. Decimal wheel on one small group

After the game, we gave another contextual problem of decimals related to the decimals addition. We briefly took one example of the students' answer (Fig. 9). From the picture, we asked prospective teachers to give as many as possible answers that became elementary students' answer of thinking. This is useful for the prospective teachers to know from the start what the answer can be. So they can prepare a good answer or an easy explanation.

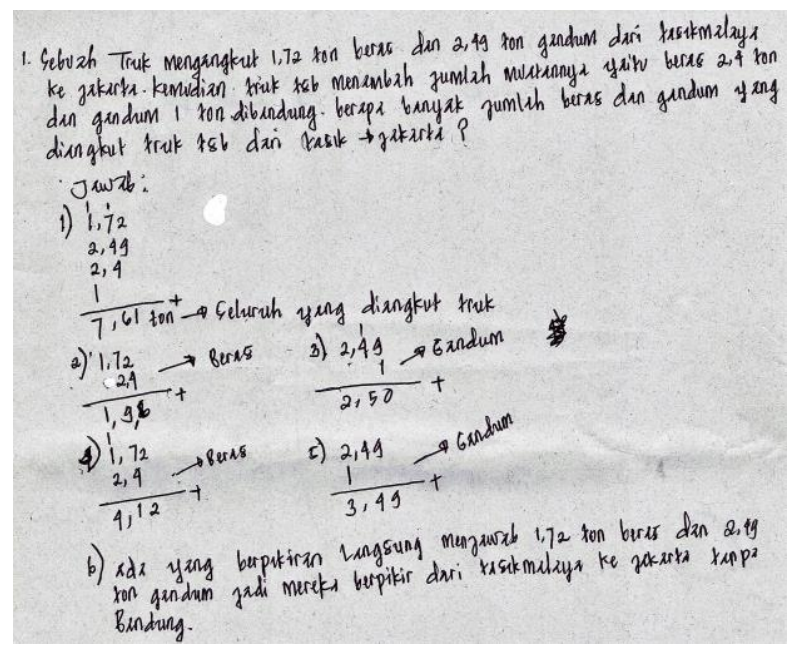

Fig. 9. One of the students' answer in solving contextual problem of decimals addition.

Finally, on the last subtopic that was percentages, we came up with the contextual percentage problem which provided with percentage bar as a model for. However, there were many different ways of answering from the students. We could call it as a 'model of'. On the figure 10, we tried to focus on number $2 b$.

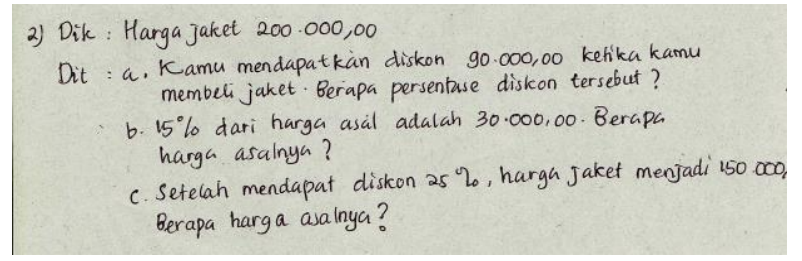

Fig. 10. One example of contextual percentages problem.

On number $2 b$, the students were asked to find the real price of the jacket when there was a situation that $15 \%$ of the real price was Rp30.000. There were some different answers from prospective teachers showed on the figure (Fig. 11). We could see from the answers that the model of and model for percentages appeared. Therefore, prospective teachers' understanding of percentage were good enough, from the basic one till the existed complicated one.
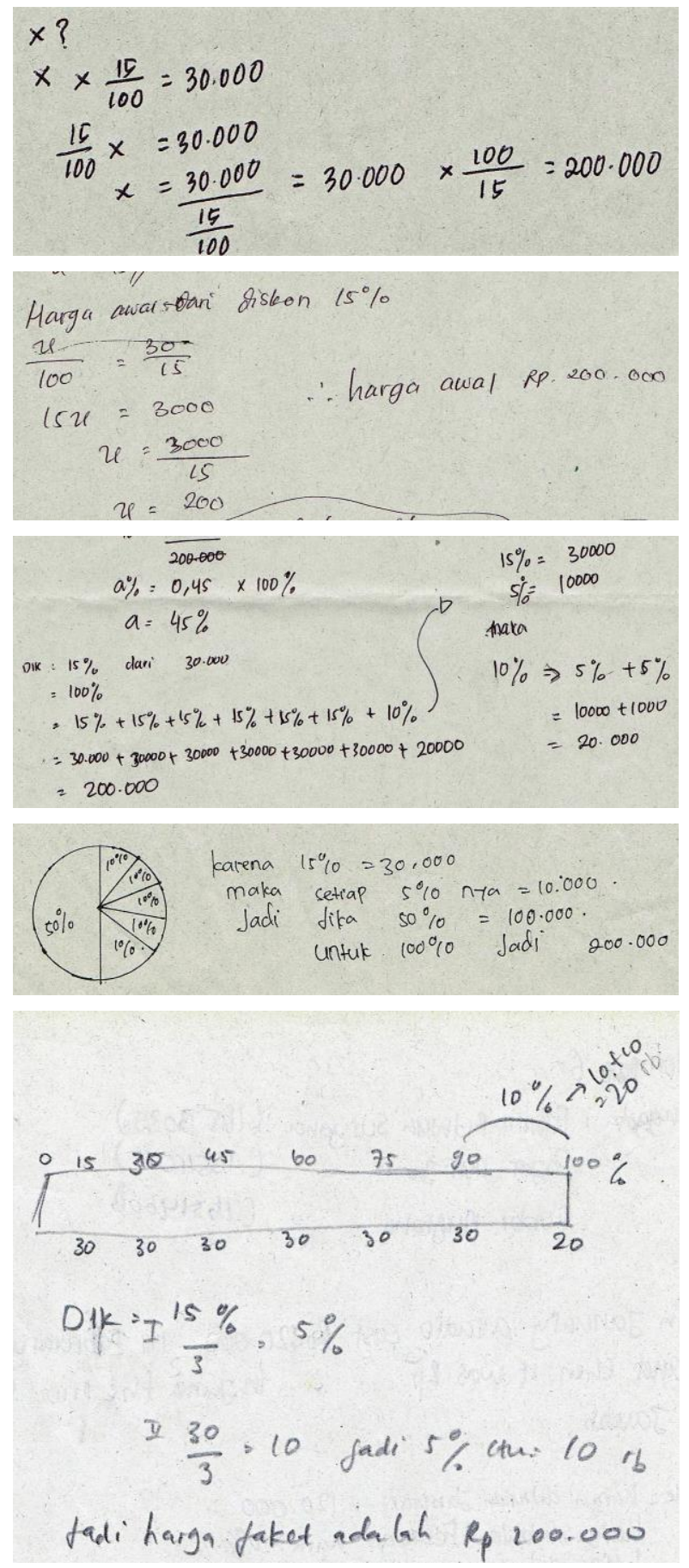

Fig. 11. Five students' answer for number $2 b$.

\section{ACKNOWLEDGMENT}

Thanks to one of my supervisor, Dr. Jarnawi Afgani Dahlan, M. Kes., who had guided me in constructing the instrument of this research. 


\section{REFERENCES}

[1] E. A. Afriansyah, "Design Research: Konsep Nilai Tempat dalam Operasi Penjumlahan Bilangan Desimal di Kelas V Dekolah Dasar," Master thesis on SPS UNSRI-UTRECHT: Unpublished, 2012 ${ }^{\mathrm{a}}$.

[2] E. A. Afriansyah, "Implementasi PMRI dalam materi sifat komutatif dan asosiatif pada bilangan bulat untuk level siswa SD/MI," Mosharafa Journal of Mathematics Education, 11th Ed No. 3: 19-25, $2012^{\mathrm{b}}$.

[3] E. A. Afriansyah, "Design Research: Place Value in Decimal Numbers Using Metric System," International Seminar on Mathematics, Science, and Computer Science Education MSCEIS. Universitas Pendidikan Indonesia (UPI) Bandung., 2013.

[4] E. A. Afriansyah, "What Students' Thinking about Contextual Problem is," International Seminar on Innovation in Mathematics and Mathematics Education ( $1^{\text {st }}$ ISIMMED). Universitas Negeri Yogyakarta (UNY): Yogyakarta, 2014.

[5] A. Bakker, "Design Research in Statistics Education. On Symbolizing and Computer Tools," Amersfoort: Wilco Press, 2004.

[6] N. Bezuk and K. Cramer, "Teaching about Fractions: What, When and How?" in P.Trafton (Ed), National Council of Teachers of Mathematics 1989 Yearbook: New Directions for Elementary School Mathematics (pp 156-167). Reston, VA: National Council of Teachers of Mathematics, 1989.

[7] Crow dan Crow, "Introduction to Education (New Revised Ed)," New York: American Book Company, 1960.

[8] Darhim and Hamzah, "Antara Realistic Mathematics Education (RME) dengan Matematika Modern (New Math)," 2010.

[9] H. Freudenthal, "Mathematics as An Educational Task," Dordrecht, The Netherlands: D. Reidel Publishing Company, 1973.

[10] H. Freudenthal, "Didactical Phenomenology of Mathematical Structures," Dordrecht. The Netherlands: D.Reidel Publishing Company, 1983.
[11] H. Freudenthal, "Revisiting Mathematics Education: China Lectures," Dordrecht, the Netherlands: Kluwer Academic Publisers, 1991.

[12] K. Gravemeijer, "Developing Realistic Mathematics Education," Utrecht: Technipress, Culemborg, 1994.

[13] K. Gravemeijer, "Local instructions theory as means of support for teachers in reform mathematics education. Mathematical Thinking and Learnin,”, 6(2), 105-128, 2004.

[14] K. Gravemeijer and P. Cobb, "Design research from the learning design perspective," Educational design research (pp. 17-51), London: Routladge, 2006.

[15] R.K. Sembiring, Hoogland, K., and M. Dolk, "A Decade of PMRI in Indonesia," Utrecht: APS International, 2010.

[16] G. G. Thompson, E. F. Gardner, and F. J. D. Vesta, "Educational Psychology," New York: Appleton-Century-Crofts Inc., 1957.

[17] Turmudi and A. Jupri, "Guided Reinvention in Mathematical Modelling," Presented in the $2^{\text {th }}$ International Conference on Lesson Study, August, $1^{\text {st }} 2009.1-5,2009$.

[18] A. Treffers, "Three dimensions. A model of goaland theory descriptions in mathematics instruction - the Wiskobas Project," Dordrecht: Reidel Publishing Company, 1987.

[19] M. Van den Heuvel-Panhuizen, "The didactical use of models in realistic mathematics education: An example from a longitudinal trajectory on percentage," Educational Studies in Mathematics, 54, 935, 2003. 